\title{
Why Poetry Matters beyond Figures
}

SEDAKOVA O. (2019). VESCSHESTVO CHELOVECHNOSTI [A MATTER OF HUMANITY]. MOSCOW: NEW LITERARY OBSERVER. 648 P. ISBN 978-5-4448-0970-9. (IN RUSSIAN)

\author{
Alexander Markov \\ Doctor of Philological Sciences, Full Professor, Chair of Cinema and Contemporary Art, \\ Russian State University for the Humanities \\ Address: Miusskaya Sq., 6, Moscow, Russian Federation 125993 \\ E-mail: markovius@gmail.com
}

A collection of interviews given by the prominent Russian poet Olga Sedakova covers a wide range of topics both of the world and Russian social life. Sedakova is famous as a major representative of metaphysically-concerned poetry, an art theorist, and maybe a guru of interpretations of the most different phenomena ranging from primitive rites to contemporary social movements. Her subtle, clear, and rhetorically abundant inventions about the great poets of the European tradition from Sappho to Celan that are produced in the book are excellent interventions of philosophical criticism in the mood of Paul Valéry or Thomas Stearns Eliot. About three decades of her intellectual work, from 1990 to 2018 , now are available in an informative and annotated edition.

These interviews are not the best matter for an account of celebrity studies since they have no part in the pop-star industry or successful self-representations. Quite the opposite, these texts are reports of an author who is rarely read in Russia. Sedakova's writing activity starts from early 1970's, but it was limited to Samizdat or incidental academic publications. A need for the reassembling and a general interpretation of this activity was crucial for all of the collocutors in this book.

While the danger of a misreading of the Samizdat publications from the side of the broader public was real, this proposed interpretation by the author herself lays not in aesthetical presuppositions, but in her general communicative ethics based on both aristocratic and democratic values. They include sincerity, an interest to the form of speech, and the moderate use of social and political keys to artwork, all of which are aimed not to inscribe intrinsical intentions to the authors. In a word, it is the ethics of trust as opposed to Soviet officially-recommended ethics of suspicions, vigilance, and security. ${ }^{1}$ This new ethics allows Sedakova to bring pedagogics and sensitivity together, although not in Rousseau's sense of the éducation sentimentale, but in the proper mimetic sense of classical culture: here, she says that "I call education (in Russian here kul'tura, culture) the development of direct sensual perception, as how to see or how to hear" (p. 55). The

\footnotetext{
(C) Markov A., 2019

(C) Centre for Fundamental Sociology, 2019

DOI: $10.17323 / 1728-192 \mathrm{X}-2019-3-359-363$

1. These Soviet practices of vigilance and preventive aggression, taken by the common people as "natural", are satirically depicted in Sedakova's travelogue A Voyage to Bryansk (1984).
} 
Soviet person (taken here as the social norm in the era of Stagnation) sees and listens only to "the necessary", and the culture in this mimetic understanding justifies a more plausible experience of the senses.

Her demand of tolerance towards any polemical attacks, that is, the forcing of "to listen" and to respect any private opinion, challenges European cultural habits. One should remember that Lucian of Samosata, Saint Jerome, Martin Luther, Denis Diderot and many others were very sensitive to any criticism of their writings. Sedakova mentions the presumed "openness to discussions" in the narrow circles of 1970s Russian intellectuals (p. 111) as the first experience of public responsibility and democratic development, after decades of coercive social organization. She is an enthusiastic supporter of classical erudition as the new piety in the school of the balanced analysis of complex cultural processes, and as an antidote to ideologies or simplifying interpretations. Humanities as necessary for an open democracy is her beloved social idea, an idea close to Martha Nussbaum or Barbara Cassin, but Sedakova makes less of a difference between cultural processes and normative texts than her Western colleagues.

To further clear it up, we need to take the intellectual project by Sergey Averintsev (1937-2004), the Russian scholar, public intellectual, and the most cited Russian writer in the book, seriously. ${ }^{2}$ Averintsev was a person of deep erudition in Greek, Roman, and Byzantine antiquities, and was recognized as a leading expert. Under Soviet rule, this legal status allowed him to give actualizing interpretations of key ancient and Christian texts, showing how the structure of these texts "works", that is, how these texts create cultural patterns for a chain of generations. Sedakova, in one of her poems, uses the metaphor of "generational surf" as a principle of Christianity where religion is centered not about rites or heritage, but on the common choice of the new way of life.

Averintsev's main task was to inscribe Byzantine and Russian culture in the general movement of Western culture, disputing the underestimation of Byzantine intellectual experience. He cited mostly German theorists of culture from Schelling to Curtius, but his approach stays near to the archeology of terms (notions) and ways of life as promoted by the College de la Sociologie or by Foucault, although not to German processual speculations. We find a homage to German idealism along with a practical use of French theory in the book, particularly when Sedakova approves of the Heideggerian non-manipulative hermeneutics of poetry. This is in opposition to the scientific trends in today's humanities underlining not the idea of the anticipated self-development of poetic language but the idea of the autonomous work of art, forming its space and its reception. This side of Heidegger's approach to art was the most influential for René Char and the later French reception of Heidegger.

Thus, "How does it work?" is the drastic question of Sedakova's answers. When we read through the book, the most bizarre moments are not the questions about the ways

2. On Averintsev's project of cultural history of Byzance and the West and the styles of Sedakova's poetry, refer to the deep and insightful remarks in: Kukulin I. (2019). Stylized Folklore as a Recollection of Europe // Sandler S., Khotimsky M., Krimmel M., Novikov O. (eds.). The Poetry and Poetics of Olga Sedakova: Origins, Philosophies, Points of Contention. Madison: University of Wisconsin Press. P. 271-294. 
of art in contemporary world, but the answers about how art and poetry recast human life. "How it is made?" and "how does this element work in artwork and art progress?" were the orienting questions of Russian Formalism, and Sedakova declares her sympathy to the heritage of this scholarly movement. However, she denies the very idea of art's progress by advocating the contingent epiphanies of sense, and citing Joyce, Proust, and Pasternak on epiphanies.

Why approve such a method, but reject its historical ambitions? In Soviet times, nonofficial intellectuals often addressed their enthusiasm of the representatives of old-regime erudition or of the early Soviet avant-guard. They not only imitated their responsibility in research and writing, but also their habits, manners, and even idiosyncratic wonts. It was the way to reintroduce the norms of intellectual production that were distorted or discarded in the mobilization of Soviet ideological service. In Sedakova's view, Averintsev took a particular place in this mimetic restoration since he denied any subordination in cultural production, but took any reasonable statement as necessary. In contesting any historical ambitions of this mimetic quasi-aristocracy or snobbery, Averintsev was definitely democratic in his views, in spite of his visible hieratic manner of speech and behaviour and in spite of his subtle argumentation that demanded a great erudition to be accepted by the public. His manner of writing stood closer to Aby Warburg in mixing sociological and psychological arguments with a large amount of data from philosophy and religion. Thus, his death was a greater loss for democratic erudition than for the snobby specializations in humanities, or as Sedakova says, "I'm deeply concerned for the lack of presence of him in our today culture; even in university circles they talk a little about him now" (325). The reference to university is striking here. Emphatically, it means Moscow State University as the flagship of classical education, but in general, it means that the educational curricula in Russia are now much more oriented to special trainings, not to the humanities as an experience of openness and empathy for different cultures and their phenomena.

For Sedakova, any interview is an instrument to reconstruct a deep history of her creative inspiration that goes back to her childhood. This inspiration, she says, has nothing to do with the appropriation of things, and she opposes a childish fascination to any kind of appropriative activity. She often criticizes literary representations of childhood as outdated, and says that "I guess, that thanks to our times I can see something even inaccessible for Pasternak" (309). Sedakova often appeals to Pasternak as the expert in the early creative experience, but what has changed with the epoch? In Pasternak's prose, e.g., Zhenia Luvers' Childhood (1918), the impossibility of any appropriation of early personal feelings is a kind of historicist alternative to modernity. In Aristotelian terms, Pasternak's life is potence, a chance for another history, and Sedakova's life is energy, the actual generosity as the acting out of the poetry of life. This energy unites intuition and understanding, which is illustrated when she writes that "to understand means [for me] to be around in, for a time" (p. 593).

Sedakova avoids the term trauma in her descriptions of totalitarian systems of individual unpleasant experiences, since, for her, “The idea of traumas or any psychical inju- 
ries is not my cup of tea. Our first need is to go far from our obsessions" (p. 506). Some philippics against actual trends are justified with this critique of simple explications and formulae. In her anti-Freudian conception of childhood, the avoidance of formulas is the main principle of the formative and existential character of all notable early recollections. Let the traumas be the subject of special professional treatment, since the general nonspecified experience, she says, is a radically different other thing.

Sedakova often describes this recollection as the fascinating feeling of general sympathy for all things, of the best choice, and of the magic aura of all things that are not qualified and branded as useful or necessary. A special competence of hers is the flawed aspect of the general worldview, and in one place, she compares the merits of Tolstoy and Gorky. She writes that Gorky, who was extremely popular around the world, is an episode of Tolstoy's creation and is a "secondary hero" (p. 462) of Tolstoy's prose conception. She writes that "All of them could be imagined as secondary heroes in a great novel by Tolstoy, Gorky himself, and other leaders of the era. They would have not even reached to the scale of Ivan Ilyich" (Ibid.). We need to note that this transparency of literature, life, and hypothetical nomadism from books to social reality and vice versa was invented in Russian modernism to defeat the previous pragmatism of the left-wing Russian intelligentsia, thus disproving Chernyshevsky's conception of literature as the modeling of social morality. Sedakova says that for her, Pasternak, not Nabokov, was the main critic of the Russian intelligentsia's obsession with common places and social instructions. In Doctor Zhivago, Pasternak opposed the common places of Strelnikov's mind to artistic improvisations and Zhivago's mystical dreams. Sedakova puts light on this dilemma of rule-obedience (as a basic of social compromise) and of the artistic soul (as the principle for new forms of activism) by taking its best expression in War and Peace by Tolstoy, where the honest person, Princess Maria, is less sympathetic than the puerile Natasha.

In her strong criticism of the intelligentsia, Sedakova involves historical arguments. An intellectual "introduces speech, that ... not only describes, but also constructs reality” (p. 380). Construction for Sedakova is a synonym for meta-description, and she favors intellectuals in Foucault's sense as masters of rhetorical description, involuntarily supporting a norm of classical education. Russian intelligentsia, she says, was obsessed with the idea of folk or the common people (narod), and this negative identification (that is, intelligentsia defined as non-folk) was the fate of Russian culture. The incommutable pragmatism of this negative manipulation, in her opinion, undermined the subtle practices of life-creation of Russian modernism.

Sedakova reproaches intellectuals for their claims to regulate social interests and to provide civil consensus. She says that these regulations often turn out to be group projects, lacking real open-mindedness. Her moral authorities would be Mother Teresa or Médecins Sans Frontières, or the Popes of the last decades as the poets of real life. A spiritual interest is one of the necessary demands for these people. For example, Sedakova tells how, in Soviet times, Averintsev was a kind of spiritual man for his fans, and they "brought their children under his blessing" (p. 238), expectinga healing power from his body. We may refer to Averintsev's will as only one occupation to be written on his tomb, 
Sergey Averintsev, $\alpha v \alpha \gamma v \omega \dot{\omega} \tau \eta \zeta$; the Greek word means reader, alluding to his bookish life, not to the lowest function of the Church's clergy.

Some interviews are dedicated to the theory of translation, which is a social project for Sedakova. Her remarks are acute on what, how, and for what purposes translating is subordinated to the vision of the Russian culture as part of the world cultural process and as a sandbox of innovations in literary strategies. She tries to solve the discussion of Russian intellectuals from Slavophiles to émigré thinkers to whether the Byzantine or the Slavic heritage was the fate of Russian culture in provoking isolationist trends from the West, or was the resource of development of authentic forms of phantasy which is seminal for the great Russian novel. Sedakova sees the lack of her predecessors in that they saw any translation as artifact, and not as energy. Sedakova says that real translation transforms the translator themselves, providing freedom from vagaries and "neurotic complexes that some people cherish and try to save for a lifetime" (138), and historicizes the personality of the translator much more than the translated works. A sense of history and personal responsibility, she argues, should not be based on ready-made models, but on the adventure of translation.

This translation study is an introduction for Sedakova's theological statements concerning any Church as place for freedom from neuroses and whimsies. This image of the Church, I suppose, partly owes to the freedom experience of hippies and other spiritually-motivated communities of the 1960s-70s.

The book is beautifully framed, with an index of the first publications of the interviews. In the book, some interviews are entitled differently than in the first publication, and this is indicated in the last pages. I found no significant typos. Unfortunately, there are several layout failures, and the margins that are too wide are not quite appropriate for the design. An index of names or objects mentioned in the book is missing, and the footnotes are given only bibliographically, not everywhere. Therefore, the book is intended not so much for research work but as for reading. We believe, that not only a specialist in contemporary Russian poetry, but also an expert in intellectual history cannot do without this book. We hope that it will take its place among the program of works about Soviet culture, like the works of Michael Epstein, Alexander Etkind, and others.

\title{
Почему поэзия значительна и без риторических фигур
}

\author{
Александр Марков \\ Профессор кафедры кино и современного искусства Федерального государственного бюджетного \\ образовательного учреждения высшего образования «Российский государственный гуманитарный \\ университет» \\ Адрес: Миусская площадь, д. 6, Москва, Российская Федерация 125993 \\ E-mail:markovius@gmail.com
}

Рецензия: Ольга Седакова. Вещество человечности. Интервью 1990-2018 (Москва: Новое литературное обозрение, 2019). 